\title{
Ulster Exclusion and Irish Nationalism: Consenting to the Principle of Partition, 1912-1916
}

L'Exclusion de l'Ulster et le nationalisme irlandais : consentir au principe de la partition, 1912-1916

\section{Conor Mulvagh}

\section{(2) OpenEdition}

\section{Journals}

Electronic version

URL: http://journals.openedition.org/rfcb/3773

DOI: $10.4000 /$ rfcb.3773

ISSN: 2429-4373

Publisher

CRECIB - Centre de recherche et d'études en civilisation britannique

Electronic reference

Conor Mulvagh, «Ulster Exclusion and Irish Nationalism: Consenting to the Principle of Partition, 1912-1916», Revue Française de Civilisation Britannique [Online], XXIV-2 | 2019, Online since 19 June 2019, connection on 09 July 2019. URL : http://journals.openedition.org/rfcb/3773; DOI : 10.4000/ rfcb.3773

This text was automatically generated on 9 July 2019.

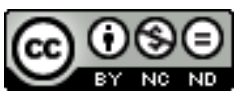

Revue française de civilisation britannique est mis à disposition selon les termes de la licence Creative Commons Attribution - Pas d'Utilisation Commerciale - Pas de Modification 4.0 International. 


\section{Ulster Exclusion and Irish Nationalism: Consenting to the Principle of Partition, 1912-1916}

L'Exclusion de l'Ulster et le nationalisme irlandais : consentir au principe de la partition, 1912-1916

Conor Mulvagh

\section{Introduction ${ }^{1}$}

1 In settling the so-called "Irish question" between 1912 and 1922, two outcomes which could not have been foreseen at the outset were that six of Ireland's thirty-two counties would be excluded from the jurisdiction of a Dublin parliament and that a majority of Irish nationalists from those counties would consent to time-limited exclusion. This article has two main aims. The first is to examine the thinking behind the Government's decision to exclude six full Ulster counties from the jurisdiction of the proposed Irish Home Rule parliament. The second is to chart the gradual elicitation of a deeply reluctant consent for exclusion, first from the Irish Nationalist political leadership and then from the nationalist communities affected. As nationalists saw it, they were being asked to endorse a strictly time-limited measure. However, explicit assurances that the exclusion would be permanent were simultaneously included in government dossiers and, by 1916, given in writing to Ulster Unionists in a move that would ultimately collapse the efforts of the British government to solve the Irish question in 1916. The eventual resolution of the issue would take another five and a half years and cost of several thousand lives through the outbreak of guerrilla warfare in the south and sectarian pogroms in the north of the island.

On 11 April 1912, the third attempt to pass Home Rule legislation for Ireland was introduced to parliament at Westminster. At the end of September 1912, Ulster Unionists had formalised their opposition to the Bill through the Ulster's Solemn League and 
Covenant, a document which pledged its signatories to defeat Home Rule "using all means which may be found necessary". The document was signed by 237,368 men and a further 234,046 women signed a corresponding women's "Declaration". ${ }^{2}$ Ulster unionist opposition had been efficiently mobilised against the two previous attempts to pass Home Rule legislation in 1886 and $1893 .{ }^{3}$ Since then, the foundation of the Ulster Unionist Council in 1905 had given further cohesion to anti-Home Rule sentiment. Both the Liberal and Nationalist party leaderships thus expected robust resistance to the third Home Rule Bill in 1912 but the "Ulster question" was lightly dismissed when Prime Minister Asquith introduced the Bill in Parliament. ${ }^{4}$

3 Behind closed doors, members of Asquith's Cabinet had been facing up to the realities of the Ulster problem for months. Lloyd George and Churchill had proposed special accommodation for Ulster to Cabinet as early as February $1912 .{ }^{5}$ However, in public, the government remained adamant that Home Rule would be an all-Ireland settlement and insisted that universal safeguards written into the Bill, including on religious freedom, would assuage the concerns of unionists and Protestants across the island. ${ }^{6}$

On 11 June 1912, a backbench Liberal MP, Thomas Agar-Robartes, introduced the first formal exclusion proposal to Parliament when, on the assertion that "I have never heard that orange bitters will mix with Irish whisky", he moved an amendment proposing the exclusion of the four Protestant majority Ulster counties. ${ }^{7}$ Walter Long, the Conservative MP and former Irish Chief Secretary, feared that this was a "very open trap" designed to open up a schism within Unionism between those who would accept exclusion for a portion of unionist Ulster and those who were not prepared to abandon the more isolated pockets of unionism in Ireland's three other provinces. ${ }^{8}$ While Long was keen to continue his opposition to Home Rule on an all-Ireland basis, the majority of unionists in both Ireland and Britain now favoured some special consideration for the north-eastern portion of Ulster, as an insurance policy should Home Rule be passed for the rest of Ireland. ${ }^{9}$

The exclusion proposal highlighted the division between unionists in Ulster and those in the rest of the island. While southern unionists hoped for universal safeguards, Ulster unionists began to concede that Home Rule would become law in three of Ireland's four provinces. While accepting that the fate of unionists outside Ulster was all-but-sealed, Ulster Unionists and their allies doubled down on their resolve to ensure by any means necessary that the province would not be ruled by a Dublin parliament. The leader of Ulster unionism throughout this period was the Dublin-born barrister and MP Sir Edward Carson. At a time when compromises of all types were being proposed for Ulster, Carson pushed an agenda of intransigence. In private, Carson's view on the size of an excluded “ Ulster" was more nuanced. On 20 September 1913, in an often-quoted letter to Andrew Bonar Law, Carson explained that "my own view is that the whole of Ulster should be excluded but the minimum would be the six plantation counties, and for that a good case could be made."10 Publicly, however, Ulster unionism would not flinch under the various concessions being offered..$^{11}$ Instead, Ulster Unionists focused on preparing their resistance should an attempt be made to impose Home Rule upon them..$^{12}$ In the background, the British Unionist party, which had been reformulated from the Conservative and Liberal Unionist party in 1911, saw the Irish question, and Carsonism in particular, as the stick with which to beat the ruling Liberal party. Their opposition to the government was intensified since the 1911 Parliament Act removed the House of Lords' veto: an in-built safeguard for Conservatives against any objectionable Liberal legislation emanating from the House of 
Commons. ${ }^{13}$ Ronan Fanning notes how British and Ulster Unionists saw the Parliament Act as "revolutionary" and, that "perhaps we have our one and only chance of defeating it by counter-revolutionary means." 14

\section{The Covenant, a year on}

6 In the closing days of September 1913, a series of events occurred which jump-started discussions on the Ulster crisis following months of relative stasis. Firstly, on 24 September, six leading Unionists led by Sir Edward Carson put their name to a document proclaiming a provisional government for Ulster in the event of the province "being Forcibly Subjected to a Nationalist Parliament and Executive." ${ }^{15}$

That weekend, a rally of 12,000 members of the Ulster Volunteer Force assembled outside Belfast at the Balmoral Agricultural Showgrounds. During the demonstration, two flags were flown. Firstly, a Union Jack, believed to be the largest ever in existence, was unfurled. Second, a new flag for the breakaway province of Ulster was flown for the first time. It had "a red hand and stars of each county of the new state of Ulster."16 In the wake of these two events - the launch of a provisional government and a show of strength by Ulster's rebel army - the British Unionist leader Andrew Bonar Law met with Winston Churchill and told him the Tory party were now open to holding a conference and that they had Carson on board.

The next day, on 28 September, at the other end of Ireland, the leader of the Home Rule movement, John Redmond, visited the ancestral home of the nationalist hero Daniel o'Connell and, en route, gave a firm statement of his party's position. He unambiguously rejected the idea that Ulster could be excluded from any Home Rule settlement. ${ }^{17}$ While holding the door open to negotiation on any issue save that of exclusion, Redmond managed to stoke rather than ease tensions when he told his audience that "the whole agitation in Ulster was but a gigantic and preposterous absurdity." 18

Irish nationalism was at this point dominated by the Irish Parliamentary Party, the pledge-bound elected MPs who consistently held approximately three quarters of Ireland's seats in the House of Commons. Around John Redmond, the party chairman, his three closest advisers were John Dillon, MP for Mayo East and the former leader of the majority faction of Irish nationalism in the 1890s, T. P. O'Connor, the IPP's only MP to sit for a British constituency in the strongly Irish city of Liverpool. The fourth and youngest member of this inner circle was Joseph Devlin, Secretary of the United Irish League from 1904, President of the Ancient Order of Hibernians from 1905, and, since 1906, MP for his native West Belfast, a Catholic enclave within the otherwise Protestant majority city. ${ }^{19}$

T. P. O'Connor played an important role during the Home Rule crisis. Resident in London, O'Connor, a major media mogul, was close to leading members of the Liberal political establishment, especially David Lloyd George. On 30 September, at the request of the Prime Minister, Lloyd George sent for O'Connor and sought to ascertain the outlook of the Irish party in light of recent developments. ${ }^{20}$ Immediately after the meeting, O'Connor wrote to his friend and Irish party colleague John Dillon outlining the view he had formed during the meeting that concessions on control of education or even time-limited exclusion for the north-eastern counties were now worth considering. O'Connor explained how 
L[loyd] G[eorge] certainly sees all the difficulties of our assenting to the exclusion of Ulster - I mean, of course, in saying Ulster the four counties: - the desertion of our friends etc. ... It is evident to me that the Tory Party as a whole, is somewhat alarmed by the position of Carson and would grasp at any compromise which would save their faces. ${ }^{21}$

o'Connor found that Dillon was away so, the following day, he wrote to Devlin explaining how:

[Lloyd George] had proposed at the beginning of the struggle that Ulster sh[oul]d get this option [of a plebiscite], feeling confident then that it would be refused, and that he still thought this would have been wise tactics. ${ }^{22}$

[We] discussed quite calmly and amicably our difficulty in agreeing to a proposal which would look like the betrayal of our fellow-Nationalists in Ulster. ${ }^{23}$

Devlin, Dillon, and Redmond all passionately felt the absolute necessity that no consideration should be given to concession, and that the rights of nationalists in all four provinces should be defended at any cost. By contrast, O'Connor had now revealed that he was willing to throw a still undetermined portion of Ulster open to a plebiscite.

Redmond, Dillon, and Devlin remained confident that the Home Rule Bill would become law through its preordained constitutional pathway. As a sign of good faith, and to reinforce the message Redmond had delivered at Cahirciveen, Devlin took it upon himself to write to the Chief Whip of the Liberal party, Percy Illingworth, on 7 November 1913. Devlin explained that his letter was "purely personal and commits no one, but contains facts they [the Liberal party] ought to know." ${ }^{24}$ Devlin told Illingworth that there was widespread distaste for any "shilly-shallying" over the resolution of the Ulster question and that on a recent tour of Britain, "one note sounded clearly ... the note of "No Compromise." 25

Having found the Irish party intransigent, the Government was now forced to give some level of recognition to the growing potential for trouble in Ulster. What should be remembered is that all of this occurred before 25 November 1913 when the pro-Home Rule Irish Volunteers were founded and thus the only extra-parliamentary force in Ireland was the Ulster Volunteer Force. Faced with the growing popularity of paramilitarism among Ulster unionism, the government sought to assuage Carsonism. Having refused to agree voluntarily to compromises, the Irish party would now be prevailed upon to make concessions for Ulster.

Throughout the period O'Connor had been urging his colleagues to outline a clear Ulster policy to the Prime Minister. Asquith had been receiving more readily offered suggestions from the Unionist side. Andrew Bonar Law had met Asquith in early November and had outlined his position, again in a purely personal capacity. While open to definitions on the geographical shape of the excluded area, Bonar Law explained that only permanent exclusion would satisfy the Unionist party. Hinting at the power behind his position and the relative moderation of his stance, Bonar Law reminded Asquith that "he could not, of course, speak for the extreme men amongst his own supporters or amongst the supporters of Carson in Ulster." 26

At a time when much of these policies was being articulated from speaking platforms and in the press, the government urgently sought an opportunity to sit down with the Irish party and talk. On 13 November, Asquith wrote to Redmond requesting a meeting explaining that he was

... anxious to have a talk with you [...]

I feel that in your speech at Newcastle you will be careful not to close the door to the possibility of an agreed settlement. 
I will only add, for the moment, that I am by no means sanguine that anything of the kind can happen. Nor need I assure you of the firm and unshaken determination of my colleagues and myself to attain with your help our common object. $^{27}$

17 On 17 November 1913, two meetings were held at Downing Street. In the morning, the Prime Minister spent approximately an hour with Redmond. In the afternoon, Lloyd George met Dillon with Percy Illingworth in attendance. In his meeting with Redmond, the Prime Minister reported the contents of the conversation he had recently had with Bonar Law. Asquith then discussed Ulster in frank terms with Redmond. He expressed his concern, which was shared by the Cabinet, that it was now necessary to work towards " some settlement which would avoid bloodshed in Ulster." 28 Asquith warned Redmond that:

the Carsonites were in possession of at least five thousand rifles - probably more and his information from the War Office with re-[gard] [sic] to the attitude of the Army was of a serious character, pointing to the probability of very numerous resignations of commissions of Officers in the event of the troops being used to put down an Ulster insurrection. ${ }^{29}$

In his meeting with John Dillon, Lloyd George disclosed a separate but related revelation: that the authorities had uncovered 95,000 rounds of ammunition in Belfast and were working towards their seizure. ${ }^{30}$

Three points of major significance arise from these meetings. Firstly, by November 1913 Ulster Unionists were showing their teeth and putting force behind their rhetoric through major munition importations. ${ }^{31}$ Secondly, the British government was fully aware of these shipments. Finally, and most importantly, these facts were being used by the British government in order to turn the screw on the Irish party and to extract concessions from Redmond and Dillon.

Although both Asquith and Lloyd George were keen to stress that they in no way envisaged offering concessions to Ulster immediately, the direction favoured among the Cabinet was a scheme which had been drawn up by Lloyd George. It would have seen Ulster (or a portion thereof) excluded from the jurisdiction of a Home Rule parliament for a period of five years after which time Ulster would automatically move from Westminster to Dublin control. All that the Government were asking at this point was that the Irish party agree to the principle of this concession and that they would not discount the possibility of compromise in the future. As Asquith put it to Redmond, "we must, of course, keep our hands free, when the critical stage of the Bill is ultimately reached, to take such a course as then in all circumstances seems best calculated to safeguard the fortunes of Home Rule."32

21 Whereas an official shift in in the Irish party leadership's stance would not come until March 1914, in acquainting Redmond with the facts of the Ulster situation, Asquith had succeeded in winning another convert, in principle only, to the idea that a special accommodation for Ulster would have to be made. According to Lloyd George's memoranda of his interviews with Dillon, he extracted an even more emphatic approval for the idea of temporary exclusion "inasmuch as it was accompanied by the carrying into law of Home Rule for the rest of Ireland". ${ }^{33}$ F.S.L. Lyons questions the credibility of Lloyd George's interview, believing a situation where Dillon was more amenable to conciliation than Redmond to be improbable to the point of disbelief. ${ }^{34}$ However, further evidence suggests Lloyd George's memoranda should not be rubbished entirely. In a letter to O'Connor after his meeting, Dillon stated that "if we were forced to a decision now on the question of temporary exclusion of Ulster - our decision must be a flat negative." ${ }^{35}$ However, this does not mean that 
Dillon had rejected the principle of temporary exclusion. Lloyd George had been keen to stress Dillon's apprehension over the timing of an announcement of the Irish party's approval to time-limited exclusion. Dillon's concern was over 'when' rather than 'if' the Irish party would agree to the concessions.

Referring to his scheme for temporary exclusion, Lloyd George's memo noted that:

[Dillon] was anxious the Irish leaders should be free during the next few months to state that no proposal of the kind had been made to the other side, and that they (the Irish leaders) had not assented to such a scheme. He thought that if put forward at the last moment, when the Bill was going through, it [temporary exclusion] might be tactically a very wise plan to propose, and that then the Irish leaders might carry it in Ireland. ${ }^{36}$

All Dillon wished to clarify in his subsequent letter to O'Connor was that, if forced into a decision now, the party would have to reject any idea of exclusion. In this same letter to o'Connor, he confirmed this, stating that when negotiating with Lloyd George: "I kept perfectly open mind [sic] to consider the proposition [of temporary exclusion] when the time came and assented to accept it or reject it - after giving full weight to all the circumstances of the time." 37

Thus, it can be demonstrated that the Government had, by the end of November, succeeded in gaining approval, in principle, from three of the four members of the Irish party's inner leadership for temporary exclusion. ${ }^{38}$ This was a major coup and marked a fundamental shift in the stance of the Irish party.

\section{The last hurdle: Devlin}

Lloyd George had noted Dillon's concern that, while Dillon personally saw the merits of Lloyd George's scheme, "he anticipated difficulty with Devlin, whom he described as being perfectly irreconcilable in the matter of the exclusion of Ulster." ${ }^{39}$ Although Dillon did not explicitly commit to any attempt to convert Devlin, Lloyd George recorded that "[Dillon's] attitude was friendly to the proposal of the Cabinet, and it was clear that if left to him to decide, there would be no difficulty in obtaining the assent of the Irish Nationalists." ${ }^{40}$ It is thus not sensationalist to state that Redmond, Dillon, and O'Connor were keeping Devlin in the dark following their meetings at Downing Street in November. ${ }^{41}$ Having been converted to acceptance of time-limited exclusion, they now had to break the news to their Belfast colleague, but this would have to be done sensitively. Dillon seemingly dreaded the task and was anxious that Devlin should not receive any premature half-truths about the complicated nature of the arrangement he had arrived at with Lloyd George. In an early communication following his return to Dublin, Dillon chastened o'Connor, informing him that "I cannot communicate your letter to Joe Devlin - because of the sentences conveying impression that I have agreed to temporary exclusion of Ulster." ${ }^{42}$

o'Connor had brought Devlin to see Lloyd George in December and did not fare well in finding any accommodation between the two. ${ }^{43}$ Reflecting the difficulty his colleagues faced in reaching out to Devlin, O'Connor wrote to Dillon in the closing days of 1913, appearing almost to have recanted his acceptance of concessions for Ulster. He told Dillon that "[a]ny form of exclusion of Ulster will place us in an almost impossible position. I fear that we should lose Devlin and all he represents, and you know what a loss that would be to us." ${ }^{44} \mathrm{~A}$. C. Hepburn writes that the feeling in British political circles was that Devlin would 
eventually be converted by his colleagues, and that Dillon would be pivotal to this conversion. ${ }^{45}$ which exclusion might apply. It is in this phase the modern Irish border began to take shape and was first put on paper. The groundwork began immediately and, on the same week that Devlin came on side (3 March), a government white paper was drafted. Almost immediately, the three year time limit was pushed out to six and the revised white paper 
was made public when Asquith moved the second reading of the Home Rule Bill on 9 March. ${ }^{55}$ As per Lloyd George's plan, it proposed that, on petition and on a county-bycounty basis, Ulster counties would be allowed to exclude themselves from the operation of the Home Rule Bill for a yet-to-be-determined number of years. ${ }^{56}$ Exactly a month later, on 6 April, a new set of proposals was circulated to Cabinet. One of the most significant alterations between the March white paper and the April Cabinet proposal was that "the six excluded counties [were] not to be included in the Irish unit of self-government unless by their own consent". ${ }^{57}$ The government persisted for over two more years in claiming to the Irish party leadership that the proposals for exclusion were strictly time-limited. However, this document shows that, from April 1914 onwards, the British government agreed to the principle that no move would be made to coerce or impose the reunification of Ireland after its supposedly temporary partition. Given the absolute majority of Protestants - which roughly but not entirely mapped onto unionism - the possibility of any permutation of Ulster territory opting by ballot for inclusion in a Home Rule Ireland after the period of exclusion had elapsed was remote in the extreme.

Although the Lloyd George scheme was predicated on the principle of four-county exclusion, the lines of demarcation for the excluded area were still very much up in the air throughout the period from March to July 1914. At the Irish Office, Chief Secretary Augustine Birrell began requesting information and proposals for a boundary line for the excluded area simultaneous to the printing of the government's white paper. ${ }^{58}$ Birrell drew upon the expertise of three senior civil servants to help determine the shape of the exclusion zone. These were Birrell's Undersecretary, Sir James B. Dougherty; W. F. Bailey of the Estates Commissioners Office; and Sir H. A. Robinson, Vice-President of the Irish Local Government Board.

Dougherty was an Ulster-born Presbyterian and a pro-Home Rule Liberal. Bailey, meanwhile, had been secretary to the royal commission on public works in 1886 and had travelled the length and breadth of the country in this capacity ${ }^{59} \mathrm{He}$ reminded the Chief Secretary of his "rather intimate knowledge" of religious opinions in Ulster. ${ }^{60}$ As for Robinson, he came from an Anglo-Irish Protestant (Anglican) ascendancy family and was "bred for the public service." If If Robinson's 1923 memoir is to be believed, he had a close personal relationship with Birrell and was a trusted adviser to him throughout Birrell's term as Chief Secretary (1908-16). ${ }^{62}$ Robinson was seen by Birrell as an expert on the political geography and demographics of Ireland. Virginia Crossman claims that Robinson's knowledge of the Irish localities was "unrivalled within Dublin Castle". ${ }^{63}$ Robinson had played a leading role in framing and implementing the 1898 Local Government Act. This included the re-division of Ireland's 159 poor law unions into 213 rural districts contiguous with county borders. In the process, the county borders were themselves redrawn for half of Ireland's counties. ${ }^{64}$ As such, Robinson had been central to drawing the very boundaries which, sixteen years later, were at the centre of the Ulster impasse.

In his memoirs Robinson, who admitted to having been "tarred with the Unionist brush and ... not a trustworthy person from a Nationalist point of view", said that Birrell saw him as "a sort of liaison officer for legislative work between [Birrell] and the Unionists." ${ }^{65}$ Presently, the extent to which Robinson looked out for Unionist interests in proposing his boundary line will be examined. Birrell set 6 May as the deadline for receipt of proposals from his three advisers. 


\section{The Three Schemes}

\section{The Bailey Scheme}

Taking W. F. Bailey first, although his maps have been separated from their accompanying correspondence, it is possible to reconstruct from his description and tables the boundaries of the excluded area he proposed.$^{66}$ Of the three, the Bailey scheme was the most disruptive and paid little heed to existing administrative boundaries. Instead, Bailey relied on physical geography to craft a more visible border. In Fermanagh, Bailey cut straight through both of the county's parliamentary divisions, running his boundary line directly up the middle of the Erne waterways system. ${ }^{67}$ of the three schemes, Bailey's was the only one in which his accompanying notes made no acknowledgement of the scheme's temporary nature.$^{68}$ Thus, while Nationalists were still working under the premise that they had consented to temporary exclusion, one official was drawing two clearly identifiable and separate regions using west-Ulster's waterways to create a solid and discernible line of separation. ${ }^{69}$

Bailey's scheme was the most rushed of the three and included some questionable calls. Bailey proposed the inclusion of the entire parliamentary division of North Monaghan within the unionist area. ${ }^{70}$ Monaghan was a county nobody else was even considering in their permutations and the portion Bailey chalked for exclusion had a two-thirds Catholic majority. Because his boundary line sliced through existing administrative units, it was impossible for Bailey to accurately estimate how many of the almost 1.2 million people he planned to exclude from the jurisdiction of the Home Rule parliament were Catholics and Protestants. ${ }^{71}$

\section{The Robinson Scheme}

By far the most thorough of the three exclusion schemes was that devised by Sir Henry Robinson. In drawing his boundary line, Robinson took local government boundaries as his operational unit, a method the Undersecretary would later dismiss as unworkable. ${ }^{72}$ The Robinson scheme proposed the exclusion of 1,178,586 persons from the operation of the Home Rule Act. This amounted to 26.85 percent of the population of Ireland and, at $£ 4,545,708,28.58$ percent of Ireland's land by valuation. ${ }^{73}$ Robinson's exclusion zone was two-thirds Protestant and one-third Catholic. Of the three, Robinson's boundary line was the only one which explicitly considered infrastructural factors such as road and rail connections ${ }^{74}$ Even though Robinson's line was not ultimately adopted, his justifications are highly instructive in explaining the policy thinking underpinning the final shape of the Irish border, especially the inclusion of the two Catholic majority counties, Tyrone and Fermanagh, and the majority Catholic city of Derry.

On the eastern end of the boundary line, the Robinson scheme showed considerably more sympathy to Catholics than simple six-county exclusion. Robinson left south Armagh and south Down, including the heavily Catholic town of Newry, within Home Rule jurisdiction. By contrast, in the western half of Ulster, Robinson made a number of sweeping decisions that excluded large swathes of territory with solid Catholic majorities from the jurisdiction of Home Rule. 
40 Arguably the most interesting variable which Robinson considered in drawing his line was "the degrees of obstreperousness in the rival sectarian factions on the border line." 75 In terms of appeasing volatile sectarian communities, Robinson bent to both nationalist and unionist extremists. Of Crossmaglen nationalists, he opined that they "are about the warmest lot I know." ${ }^{76}$ In Fermanagh, Robinson's justification was even more illuminating. Here he justified the inclusion of an area with a 3,000-strong Catholic majority because " there has been more money spent on armament and drilling here than in any part of the county and these Enniskillen and Lisnaskea Protestant farmers are the most bloodthirsty set of ruffians I know". ${ }^{77}$ Fearing a contagion effect in Cavan and Monaghan, Robinson defended the exclusion of these districts as "there would be no peace or settlement along the whole border line if these people were left out." 78 Bailey had applied the same logic to justify the inclusion of North Monaghan and the whole of Tyrone, the Protestant minorities of which he described as being "very strong and ... better drilled and armed than in almost any part of the Province." 79

41 Despite all of his careful work and calculations, Robinson virtually cast all this aside towards the end of his letter to Birrell stating: "I expect you will find that the Ulstermen's minimum will be six entire counties in and no option ... Personally, I agree about no option [putting the matter to a plebiscite]. It will indeed mean riots when this crucial issue is announced". 80

\section{The Dougherty Scheme}

Of Birrell's three advisers, the most reluctant was his second-in-command, Undersecretary Sir James Brown Dougherty. While Bailey and Robinson replied with detailed, even enthusiastic suggestions on the $6^{\text {th }}$, Dougherty replied on the $7^{\text {th }}$ making apologies that a prior engagement had delayed him and saying how it would be " $a$ difficult, if not impossible job to construct these pens" and that "the policy of exclusion, whatever plan may be adopted, bristles with difficulties and at the moment I confess I do not see how they are to be surmounted." $" 11$

Dougherty provided his full memorandum five days later on 11 May with his comments on the merits and demerits of dividing the province by local government areas, parliamentary divisions, and full counties. ${ }^{82}$ of these, Dougherty's preference was for the scheme which was ultimately adopted: the county option. Dougherty's rationale focused largely on the administrative headache he foresaw in dealing with an otherwise excluded area in which local government boards, county councils, and existing parliamentary constituencies would be split across two jurisdictions. ${ }^{83}$

44 All three schemes recommended that Ulster's second city, Derry, which had a Catholic majority, be put into the exclusion zone. Robinson argued that it was "impossible to keep the maiden city out of the parent County".$^{84}$ Dougherty reminded his Chief Secretary that "the City of Derry has strong sentimental attractions for the Ulster Protestant, and it is the headquarters of the County administration" adding that "it is unlikely the 'Covenanters' will now consent to see the City excluded from Protestant Ulster." 85

Dougherty was a native of Garvagh on the other side of county Derry. Alongside the Catholic enclave constituency of West Belfast, the Derry conundrum seems to have been one of the cases which convinced Dougherty of the merits of whole-county plebiscites over constituency option. By having Derry's county and city constituencies vote as a 
single unit, Derry city's 56 percent Catholic majority was negated. With a reliable 54 percent overall Protestant majority, the full county looked certain to vote itself, including its maiden city, out of the jurisdiction of a Home Rule parliament. The manufacturing of majorities to suit desired outcomes had thus crept into policy thinking on the area for exclusion. If the Derry question could be solved by county option, the same logic did not settle the question of what to do with Fermanagh and Tyrone. With a combined Catholic majority of 64 percent, the decision over these two counties would impact upon an additional 204,501 Catholics for the sake of 113,755 Protestants.

Despite declaring for whole-county option, Dougherty fudged his answer to the question of whether four or six counties should be excluded. His rationale for four-county exclusion was based on the fact that such a scheme would create "a tolerably compact area" but he seems on balance to have conceded that six counties would be the more realistic outcome due to the fact that "it is difficult to see how the Ulster Covenanters in the four included Counties can abandon their brethren in Tyrone or Fermanagh." ${ }^{86}$ No more than Robinson, Dougherty was conceding to the power of force and threat in making his decisions over Ulster.

In light of the above, following the Nationalist leadership's accession to the principle of strictly time-limited exclusion in March, Dublin Castle favoured full six-county exclusion. Despite the strong preference in Dublin for full county exclusion, it has been suggested that the other permutations were not entirely cast aside. Brendan 0 Donoghue makes a convincing case that copies of various maps, including Robinson's 6 May map, were circulated among attendees at the Buckingham Palace Conference in July (discussed subsequently) when it came to discussing permutations for an area for exclusion that might be acceptable to both Nationalists and Unionists. ${ }^{87}$

As the table below illustrates, the exclusion of six full counties was the least sympathetic of the available options. However, from the perspective of administrators full county option had the advantage of being the least disruptive from a governance perspective. However, the power of unionism was the overriding factor.

Summary of the schemes for the excluded area of Ulster, May 1914.

\begin{tabular}{|c|c|c|c|}
\hline $\begin{array}{l}\text { Area and date } \\
\text { proposed }\end{array}$ & $\begin{array}{l}\text { Population of } \\
\text { Area } \\
\text { (as a percentage } \\
\text { of all-Ireland) }\end{array}$ & $\begin{array}{l}\text { Number of Catholics } \\
\text { (percentage in } \\
\text { brackets) }\end{array}$ & $\begin{array}{l}\text { Number of Non- } \\
\text { Catholics (percentage } \\
\text { in brackets) }\end{array}$ \\
\hline $\begin{array}{l}\text { Bailey Scheme } \\
\text { (6 May 1914) }\end{array}$ & $\begin{array}{l}1,197,497 \\
(27.28)\end{array}$ & $\mathrm{n} / \mathrm{a}$ & $\mathrm{n} / \mathrm{a}$ \\
\hline $\begin{array}{l}\text { Robinson scheme } \\
\text { (6 May 1914) }\end{array}$ & $\begin{array}{l}1,178,586 \\
(26.85)\end{array}$ & $\begin{array}{l}379,013 \\
(32.16)\end{array}$ & $\begin{array}{l}799,573 \\
(67.84)\end{array}$ \\
\hline $\begin{array}{l}\text { Dougherty } \\
\text { Parliamentary } \\
\text { Constituency Scheme } \\
\text { (11 May 1914) }\end{array}$ & $\begin{array}{l}1,042,494 \\
(23.75)\end{array}$ & $\begin{array}{l}309,540 \\
(29.69)\end{array}$ & $\begin{array}{l}732,954 \\
(70.31)\end{array}$ \\
\hline
\end{tabular}




\begin{tabular}{|l|l|l|l|}
\hline $\begin{array}{l}\text { Four-county exclusion } \\
\text { (Dismissed as } \\
\text { impossible) }\end{array}$ & $1,046,030$ & $\begin{array}{l}316,406 \\
(30.25)\end{array}$ & $\begin{array}{l}729,624 \\
(69.75)\end{array}$ \\
\hline $\begin{array}{l}\text { Six-county exclusion } \\
\text { (Ultimately adopted) }\end{array}$ & $\begin{array}{l}1,250,531 \\
(28.48)\end{array}$ & $\begin{array}{l}430,161 \\
(34.40)\end{array}$ & $\begin{array}{l}820,370 \\
(65.60)\end{array}$ \\
\hline $\begin{array}{l}\text { Rest of Ireland } \\
(26 \text { counties / Irish Free } \\
\text { State) }\end{array}$ & $\begin{array}{l}3,139,688 \\
(71.52)\end{array}$ & $\begin{array}{l}2,812,509 \\
(89.58)\end{array}$ & $\begin{array}{l}327,179 \\
(10.42)\end{array}$ \\
\hline $\begin{array}{l}\text { Provincial Ulster } \\
\text { counties, full } \\
\text { province) }\end{array}$ & $\begin{array}{l}1,581,696 \\
(36.03)\end{array}$ & $\begin{array}{l}(40,816 \\
(43.68)\end{array}$ & $\begin{array}{l}890,880 \\
(56.32)\end{array}$ \\
\hline $\begin{array}{l}\text { Connaught, Leinster, } \\
\text { Munster } \\
\text { (23 counties, } \\
\text { provinces) }\end{array}$ & $\begin{array}{l}2,808,523 \\
(63.97)\end{array}$ & $\begin{array}{l}2,551,854 \\
(90.86)\end{array}$ & $\begin{array}{l}(7,242,670 \\
(73.86)\end{array}$ \\
\hline $\begin{array}{l}\text { Ireland } \\
\text { (all island, 32 counties) }\end{array}$ & $\begin{array}{l}4,390,219 \\
(26.14)\end{array}$ \\
\hline
\end{tabular}

\section{The Buckingham Palace Conference, July 1914}

The culmination of the Government's efforts to solve the Ulster crisis came in July. This was after the Sarajevo crisis had broken but before the violation of Belgium's neutrality brought a not-so-United Kingdom into the War. In an effort to clear Ulster from the political landscape as the continental crisis intensified, a conference was called under the auspices of the King at Buckingham Palace, sitting for four days between 21 and 24 July. Here, representatives of both the Ulster and British Unionist parties sat opposite Lloyd George and the Prime Minister representing the Government with Redmond and Dillon representing the Nationalist party. Hepburn sees Devlin's exclusion from the Conference as notable. ${ }^{88}$

50 At the sessions of the conference, the question of time limit was set aside by mutual agreement and the opposing parties decided instead to focus on the proposed area for exclusion ${ }^{89}$ By engaging in this exercise, Redmond and Dillon further confirmed their acceptance of the principle that a certain portion of Ireland would have to be excluded from Home Rule for an undetermined length of time.

51 The Buckingham Palace Conference is often seen as the moment at which the partition of Ireland began to take shape. ${ }^{90}$ However, it has been shown here that the leadership of the Irish party had conceded in private to the principle of exclusion months before this point. In a sense, the conference was an attempt to draw both sides into the open, forcing them to make public the concessions they had already made in private. If this was the Government's intention, it backfired spectacularly. Buckingham Palace was remembered for the intransigence of both parties. As Asquith recorded, Redmond and Carson faced 
each other saying "I must have the whole of Tyrone, or die; but I quite understand why you say the same". ${ }^{91}$ The conference ended in utter stalemate.

\section{War and Rising: Nationalist desperation and Ulster exclusion} communities were needed to populate the armies of the Empire and both the Ulster and Irish Volunteer movements were tapped into in the scramble to fill the ranks. ${ }^{92}$ On 18 September, the Government of Ireland Bill was passed into law without any amendment dealing with the Ulster question. However, beside it was placed a Suspensory Act which postponed the coming into operation of the Government of Ireland Act, initially until September 1915, but this period was extended in increments throughout the war and beyond until a two-state solution was inaugurated with fresh legislation in $1920 .{ }^{93}$ jumpstarted the whole process. Just as he had played the leading role in pre-war deliberations, Lloyd George was again tasked by Asquith with settling the Irish question. ${ }^{94}$ Within days of the last rebel execution on 12 May, Devlin travelled to London to hold preliminary meetings with Lloyd George alongside T. P. O'Connor. In one of the most significant of these early meetings, Lord Northcliffe, as a friend of Lloyd George's and an Irishman by birth, met Devlin to sound out possible terms for settlement. ${ }^{95}$ In the course of their discussions, which naturally centred on the Ulster question, Devlin told Northcliffe that he felt an immediate settlement for Ireland was of paramount importance following the Rising. ${ }^{96}$ For this to have come from Devlin, as the only Nationalist leader representing Ulster, was a clear signal to Lloyd George that there was some fertile ground for a settlement in the Nationalist camp. However, a letter from O'Connor to Dillon three days later gives a little more insight into Devlin's personal misgivings on the subject. Here, O'Connor told Dillon that he had

... been with Joe almost night and day ... he [Devlin] is a man of somewhat uncertain moods, as you know, and now and then he relapses into regrets that he ever consented to help us with regard to Ulster two years ago; and things of that kind, which to me are sheer madness. ${ }^{97}$

O'Connor went on to explain that, despite these private misgivings, he was confident that Devlin would fall into line with the rest of the leadership, saying that " $[t]$ his, however, is not his [Devlin's] ordinary mood, and I think I am justified in regarding him as in entire agreement with ... Redmond and myself." "98 R. F. Foster has described Redmond as "desperate ... to achieve any settlement going" following the Rising. This extended as far as conceding to the loss of Fermanagh and Tyrone whose exclusion had been so vehemently opposed by Redmond at Buckingham Palace. ${ }^{99}$

Lloyd George's proposal was the same as his 1914 scheme in all its essential details but this time the area for exclusion was, as the government had been planning for since before the war, full six-county exclusion. The 1916 proposals would see the immediate enactment of Home Rule for twenty-six counties only, and the continued attendance of Irish MPs at Westminster for the duration of the War. Once the European conflict had ended, an Imperial Conference would be held to forge a final settlement for Ulster. ${ }^{100}$ With the Nationalist leadership now prepared to accept temporary six-county exclusion, the Lloyd George scheme would be put to a representative convention of nationalists from

Revue Française de Civilisation Britannique, XXIV-2 | 2019 
the affected counties on 23 June 1916. It would fall upon Devlin to convince his flock that their temporary sacrifice was necessary to save the dream of Home Rule for Ireland. In what Eamon Phoenix has dubbed "pre-meditated duplicity", Lloyd George gave written assurances to Carson that the border would be permanent while he simultaneously allowed Redmond to acquiesce in the belief that partition would be of a strictly temporary nature. ${ }^{101}$ This double cross is what would ultimately scupper the 1916 negotiations by the end of July. ${ }^{102}$

Returning to the Ulster Nationalist convention, the late Tony Hepburn has undertaken the most comprehensive analysis of the assembly of Ulster nationalist delegates which was held at St. Mary's Hall Belfast on 23 June 1916. Following a forty-five-minute speech by Devlin in support of a policy upon which he himself still harboured doubts, the convention voted to support Lloyd George's proposals: 475 delegates in favour and 265 against. ${ }^{103}$ Historian R. B. McDowell issued the caveat that, of the 270 delegates from Fermanagh, Tyrone, and Derry City, an overwhelming 183 (68 percent) voted against the proposals. ${ }^{104}$ McDowell's point emphasises a new division that was emerging within Ulster politics. This schism was not between nationalism and unionism but rather within nationalism itself. Taking the River Bann as a dividing line, nationalists in the east of the area for exclusion, centring on Devlin's native Belfast began to sober up to the fact that they would likely find themselves excluded from the jurisdiction of an Irish parliament under any circumstances. By contrast, nationalists of Fermanagh, Tyrone, and Derry city, finding themselves on the margins of the proposed exclusion zone hoped that they could be placed under the rule of a Dublin parliament through a revision of the boundary lines. ${ }^{105}$ Ultimately, this divide would push this latter group towards the emergent revolutionary republicanism of Sinn Féin whereas Devlin held sway among his faithful followers in Belfast.

In the context of understanding the shape of the modern Irish border and in charting the path which led to nationalist acceptance of it, the 1916 Belfast conference represents a crucial juncture and the final milestone in the trajectory which this article intends to chart. The temporary exclusion which had been agreed to in principle by the Irish party leadership in March 1914 was now endorsed by a representative assembly of nationalists from the affected area. Although partition would take years to become a reality, all of its essential parts had been assembled by the summer of 1916 .

\section{Conclusion}

The period 1912-16 witnessed a complete reversal in Nationalist policy on the Ulster question. Beginning with intransigent rhetoric about an indivisible island, by 1916 both the leaders and the followers of the Irish party had conceded willingly to the temporary partition of Ireland. However, the seeds of permanency were sown by their stance.

Nationalists at all times acknowledged the principle of consent over coercion. In practice, this signalled permanent exclusion and this maxim had been written into a secret cabinet proposal as early as 6 April 1914. Consent was part of the nationalist vision for a unified and united Ireland under Home Rule. They did not want to win a united Ireland by bloodshed. Despite their professed adherence to the principle of consent, nationalists clung to the idea that exclusion would be subject to strict legal time limits. Their logic was predicated on the idea that they could win unionists in the excluded territory over by their exemplary governance. However, so long as nationalists held on to the reasonable 
and democratic idea that Ulster should not be compelled by force to enter the jurisdiction of a Home Rule parliament, the overwhelming likelihood of permanent exclusion remained a fact.

Regarding the area for exclusion, if the principle of consent was firmly established in April 1914 then the rationale for excluding six full Ulster counties was determined by the Irish Office in May 1914. Following the impasse at the Buckingham Palace Conference in July, exclusion was hardwired into any future settlement. The point here is that both the shape and nature of the Ulster solution were all-but-set prior to the outbreak of the First World War. Nationalist delegates from the six counties were forced to go through the rigmarole of giving their approval to Lloyd George's scheme a full two years after it had been determined to be the only remaining viable option.

61 The negotiation of the Ulster question should be seen as an example of the pre-war secret diplomacy which Woodrow Wilson derided in the advent of the Paris Peace Conference. In Ulster's case, all the major players knew most (but not necessarily all) of the parameters long before these were put to the populations who would have to live with the consequences. The manufacturing of majorities prior to the holding of any plebiscite should likewise sound a note of caution to historians of Europe after the Armistice.

Irish historiography charts the origins of partition to the 1920 Government of Ireland Act; the establishment of the devolved Northern Irish state in July 1921; and the signing and ratification of the Anglo-Irish Treaty between December 1921 and January 1922. What this article demonstrates is that, six years before any of this, the scheme and shape of a permanently excluded six-county Ulster had been determined by a man who was then the Chancellor of the Exchequer but would go on to become Prime Minister from December 1916 until October 1922. In this later phase, Lloyd George oversaw the implementation of all of these ideas and witnessed the decline, departure, or death of many of the participants he had tangled with in the first phase of the crisis including Asquith, Carson, Devlin, Dillon, and Redmond.

BIBLIOGRAPHY

\section{Manuscript and archival sources}

Bodleian Library, Oxford, Augustine Birrell papers

National Library of Ireland, Dublin, John Redmond papers

Parliamentary Archives, London, David Lloyd George papers

Trinity College Dublin Department of Manuscripts, John Dillon papers 


\section{Newspaper sources}

Freeman's Journal

The Irish Times

\section{Printed primary sources}

Government of Ireland Act 1914, 4 \& 5 Geo. 5 c. 90.

Suspensory Act 1914, 4 \& 5 Geo. 5 c. 88.

Robinson, Henry Augustus, Memories: wise and otherwise (London, Cassell and Co., 1923).

The parliamentary debates (Hansard), fifth series, House of Commons and House of Lords (London).

\section{Secondary sources}

Andrews, Helen, and Lunney, Linde, “Bailey, William Frederick”, in James McGuire and James Quinn (eds), Dictionary of Irish Biography, (Cambridge, Cambridge UP, 2009).

Crossman, Virginia, “Robinson, Sir Henry Augustus”, in James McGuire and James Quinn (eds), Dictionary of Irish Biography, (Cambridge, Cambridge UP, 2009).

Dunn, Peter, "Forsaking their 'Own flesh and blood'? Ulster unionism, Scotland and home rule, 1886-1914", Irish Historical Studies, 37, no. 146 (November 2010), pp. 203-220.

Fanning, Ronan, Fatal Path: British Government and Irish Revolution, 1910-1922 (London, Faber and Faber, 2013).

Foster, R. F., Modern Ireland 1600-1972 (London, Penguin, 1989).

Gwynn, Denis, The History of Partition, 1912-1925 (Dublin, Browne and Nolan, 1950).

Hennessey, Thomas, Dividing Ireland: World War I and Partition (London, Routledge, 1998).

Hepburn, A. C., Catholic Belfast and nationalist Ireland in the era of Joe Devlin, 1871-1934 (Oxford, Oxford UP, 2008).

Jackson, Alvin, Judging Redmond and Carson: comparative Irish lives (Dublin, Royal Irish Academy, 2018).

Jackson, Daniel M., Popular Opposition to Irish Home Rule in Edwardian Britain (Liverpool, Liverpool UP, 2009).

Jalland, Patricia, “A Liberal Chief Secretary and the Irish Question: Augustine Birrell, 1907-1914", Historical Journal, xix, 2 (June, 1976), pp. 421-451.

Kendle, John, Walter Long, Ireland and the Union, 1905-1920 (Montreal, McGill-Queen's UP, 1992).

Laffan, Michael, The Partition of Ireland, 1911-25 (Dundalk, Dundalgan Press, 1983).

Lyons, F. S. L., John Dillon: a biography (London, Routledge and Kegan Paul, 1968).

McDowell, R. B., The Irish Convention, 1917-18 (London, Routledge and Kegan Paul, 1970).

Meleady, Dermot, John Redmond: the national leader (Sallins, Merrion, 2014). 
Mulvagh, Conor, "Amicable in tone yet fruitless in result: politicians, press and public and the Buckingham Palace Conference, 1914”, History Studies: University of Limerick History Society Journal, 8 (2007), pp. 77-92.

Mulvagh, Conor, The Irish Parliamentary Party at Westminster, 1900-18 (Manchester, Manchester UP, 2016).

O Donoghue, Brendan, Activities Wise and Otherwise: The Career of Sir Henry Augustus Robinson, 1898-1922 (Sallins, Irish Academic Press, 2015).

Phoenix, Eamon, Northern Nationalism: Nationalist Politics, Partition and the Catholic Minority in Northern Ireland, 1890-1940 (Belfast, Ulster Historical Foundation, 1994).

Rast, M. C., “The Ulster Unionists 'On Velvet' Home Rule and Partition in the Lloyd George Proposals, 1916", American Journal of Irish Studies, 14 (2017), pp. 113-138.

Smith, Jeremy, "Federalism, Devolution and Partition: Sir Edward Carson and the Search for a Compromise on the Third Home Rule Bill, 1913-14", Irish Historical Studies, 35, No. 140 (Nov., 2007), pp. 496-518.

Stewart, A. T. Q., Edward Carson (Dublin, Gill and MacMillan, 1981).

Stewart, A. T. Q., The Ulster crisis: resistance to Home Rule, 1912-1914 (London, Faber and Faber, 1967).

\section{Online sources}

"Provisional Government for Ulster formed in Belfast" www.rte.ie/centuryireland/index.php/ articles/provisional-government-for-ulster-formed-in-belfast [23 June 2018].

Public Records Office of Northern Ireland, Ulster Covenant online; www.nidirect.gov.uk/articles/ about-ulster-covenant [23 June 2018].

"Ulster Provisional Government Proclamation", 24 Sept. 1913 [Lot 152, Bonhams Auctioneers, 12 June 2012]. https://www.bonhams.com/auctions/20137/lot/152/ [23 June 2018].

\section{NOTES}

1. I would like to express my thanks to Jérôme aan de Wiel, Mark Coen, and the editors for their helpful comments on this article. I would also like to acknowledge the support of the EU Erasmus + staff mobility programme and Irish Research Council for the Humanities and Social Sciences for their support in carrying out part of the research presented here.

2. Public Records Office of Northern Ireland, Ulster Covenant online (www.nidirect.gov.uk/ articles/about-ulster-covenant; accessed 23 July 2018).

3. Peter Dunn, "Forsaking their 'Own flesh and blood'? Ulster unionism, Scotland and home rule, 1886-1914", Irish Historical Studies, 37, no. 146 (November 2010), pp. 205-12.

4. H. H. Asquith, "Government of Ireland Bill", 11 April 1912, Hansard 5 (Commons), xxxvi, cols 1400-1.

5. Patricia Jalland, "A Liberal Chief Secretary and the Irish Question: Augustine Birrell, 1907-1914", Historical Journal, xix, 2 (June, 1976), pp. 448-9.

6. See Michael Laffan, The Partition of Ireland, 1911-25 (Dundalk, Dundalgan Press, 1983), p. 25.

7. Thomas Agar-Robartes, "Clause 1 - (Establishment of Irish Parliament)", 11 June 1912, Hansard 5 (Commons), xxxix, col. 771 et seq. 
8. John Kendle, Walter Long, Ireland and the Union, 1905-1920 (Montreal, McGill-Queen's UP, 1992), p. 72.

9. Ibid.

10. A. T. Q. Stewart, Edward Carson (Dublin, Gill and MacMillan, 1981), p. 86 and Jeremy Smith, "Federalism, Devolution and Partition: Sir Edward Carson and the Search for a Compromise on the Third Home Rule Bill, 1913-14”, Irish Historical Studies, 35, No. 140 (Nov., 2007), p. 499.

11. Alvin Jackson, Judging Redmond and Carson: comparative Irish lives (Dublin, Royal Irish Academy, 2018), p. 118.

12. See A. T. Q. Stewart, The Ulster Crisis: resistance to Home Rule, 1912-1914 (London, Faber and Faber, 1967), ch. 6.

13. On the divergent aims and intentions of Ulster and British Unionism see Jackson, Judging Redmond and Carson, p. 126.

14. Ronan Fanning, Fatal Path: British Government and Irish Revolution, 1910-1922 (London, Faber and Faber, 2013), p. 57 (citing F. E. Smith to Carson in September 1913).

15. "Ulster Provisional Government Proclamation", 24 Sept. 1913 [Lot 152, Bonhams Auctioneers, 12 June 2012]. www.bonhams.com/auctions/20137/lot/152/; accessed 23 June 2018.

16. "Provisional Government for Ulster formed in Belfast" www.rte.ie/centuryireland/ index.php/articles/provisional-government-for-ulster-formed-in-belfast; accessed 23 July 2018.

17. Dermot Meleady, John Redmond: the national leader (Sallins, Merrion, 2014), pp. 247-8. Dillon agreed "fully and heartily" with Redmond's Cahirciveen speech: Dillon to O'Connor, 2 Oct. 1913 (TCD MS 6740/196). For a summary of the speech from an Irish unionist perspective, see Irish Times, 6 Oct. 1913.

18. Freeman's Journal, 29 Sept. 1913. See also, Meleady, Redmond: national leader, pp. 247-8.

19. This inner leadership of the Irish Parliamentary Party is examined in detail in Conor Mulvagh, The Irish Parliamentary Party at Westminster, 1900-18 (Manchester, Manchester UP, 2016).

20. O'Connor to Devlin, 1 Oct. 1913 (National Library of Ireland, MS 15,181/3).

21. O'Connor to Dillon, 30 Sept. 1913 (Trinity College Dublin, MS 6740/194).

22. O'Connor to Devlin, 1 Oct. 1913 (National Library of Ireland, MS 15,181/3).

23. Ibid..

24. Devlin to Dillon, 12 Nov. 1913 (Trinity College Dublin, MS 6730/164).

25. Devlin to Illingworth, 7 Nov. 1913 (ibid.). On the wider contexts of the Home Rule crisis in Britain, see Daniel M. Jackson, Popular Opposition to Irish Home Rule in Edwardian Britain (Liverpool, Liverpool UP, 2009).

26. All this is reported in "Interview: Mr. Redmond with Mr. Asquith [17 Nov. 1913] (Dictated by Mr. Redmond)", 27 Nov. 1913 (Trinity College Dublin, MS 6748/508).

27. Asquith to Redmond, 13 Nov. 1913 (National Library of Ireland, MS 15,165/3). Emphasis in original.

28. "Interview: Mr. Redmond with Mr. Asquith [17 Nov. 1913] (Dictated by Mr. Redmond)", 27 Nov. 1913 (Trinity College Dublin, MS 6748/508).

29. Ibid.

30. See F. S. L. Lyons, John Dillon: a biography (London, Routledge and Kegan Paul, 1968), p. 341.

31. A. T. Q. Stewart describes vividly some of the complex and sometimes daring Unionist arms importation schemes that were in operation during 1913. See Stewart, Ulster Crisis: Resistance to Home Rule, ch. 8.

32. Asquith to Redmond, 26 Nov. 1913 (National Library of Ireland, MS 15,165/3).

33. Lloyd George, "Interview with Mr John Dillon, at No. 11 Downing St.", 17 Nov. 1913 (Parliamentary Archives, Lloyd George Papers, C/20/2/4).

34. On Lyons' suspicions and justification for his stance, see Lyons, Dillon, pp. 338-40.

35. Dillon to O'Connor, 27 Nov. 1913 (Trinity College Dublin, MS 6740/213). Emphasis in original. 
36. Lloyd George, "Interview with Mr John Dillon, at No. 11 Downing St.", 17 Nov. 1913 (Parliamentary Archives, Lloyd George Papers, C/20/2/4).

37. Dillon to O'Connor, 27 Nov. 1913 (Trinity College Dublin, MS 6740/213). Emphasis in original.

38. See Lyons, Dillon, p. 340.

39. Lloyd George, "Interview with Mr John Dillon, at No. 11 Downing St.", 17 Nov. 1913 (Parliamentary Archives, Lloyd George Papers, C/20/2/4).

40. Ibid.

41. Only in mid-December, three weeks after meeting in which Lloyd George outlined the true scale and severity of the Unionist threat in Ulster did T. P. O'Connor bring Devlin to a meeting with Lloyd George (O'Connor to Dillon, 17 December 1913 (Trinity College Dublin, MS 6740/217). Dermot Meleady suggests that Devlin may have been preoccupied with the emergence of the Irish Volunteers in Dublin beginning 25 November 1913 (Meleady, Redmond: national leader, pp. 256-7).

42. Dillon to O'Connor, 27 Nov. 1913 (Trinity College Dublin, MS 6740/213).

43. O'Connor to Dillon, 17 Dec. 1913 (Trinity College Dublin, MS 6740/217).

44. O'Connor to Dillon, 30 Dec. 1913 (Trinity College Dublin, MS 6740/219). Emphasis in original.

45. A. C. Hepburn, Catholic Belfast and nationalist Ireland in the era of Joe Devlin, 1871-1934 (Oxford, Oxford UP, 2008), p. 148.

46. Redmond to Dillon, 2 Feb. 1914 (Trinity College Dublin, MS 6748/519).

47. Hepburn, Catholic Belfast, p. 148.

48. "Mr Devlin's memo", 20 Feb. 1914 (National Library of Ireland, MS 15,181/3 and Parliamentary Archives, Lloyd George Papers, C/20/2/6) cited in Hepburn, Catholic Belfast, pp. 148-9.

49. Ibid.

50. Ibid.

51. Ibid, p. 149.

52. Ibid.

53. Fanning, Fatal path, p. 102.

54. Memorandum of interview, 2 March 1914 (National Library of Ireland, MS 15,257/2); Denis Gwynn, The History of Partition (1912-1925) (Dublin, Browne and Nolan, 1950), p. 95.

55. Gwynn, History of Partition, pp. 100-1; Laffan, Partition of Ireland, 1911-25, pp. 37-8.

56. White paper lxxv (1), marked "confidential", 6 Mar. 1914 (Oxford, Bodleian Library, Birrell papers, MS. Eng. c. 7035, ff. 295-8).

57. "Suggestions for a settlement of the Irish question", marked "secret", 6 Apr. 1914 (Ibid., f. 328). It should be noted that this second document was written in the aftermath of the so-called 'Curragh Incident' but prior to the Larne Gun-running of 24-5 April.

58. See Robinson to Birrell, 5 March 1914 [enclosing a map [f. 60] breaking down the religious demographics of Ulster's local government areas but with no proposed boundary line] (Oxford, Bodleian Library, Birrell papers, MS. Eng. c. 7034, ff. 55-7).

59. Helen Andrews and Linde Lunney, "Bailey, William Frederick", in James McGuire and James Quinn (eds), Dictionary of Irish Biography (Cambridge, Cambridge UP, 2009).

60. Bailey to Birrell, 6 May 1914 (Oxford, Bodleian Library, Birrell papers, MS. Eng. c. 7034, ff. 72-3).

61. Brendan O Donoghue, Activities Wise and Otherwise: The Career of Sir Henry Augustus Robinson, 1898-1922 (Sallins, Irish Academic Press, 2015), p. 11.

62. Ibid., pp. 148-50.

63. Virginia Crossman, "Robinson, Sir Henry Augustus", in James McGuire and James Quinn (eds), Dictionary of Irish Biography (Cambridge, Cambridge UP, 2009).

64. O Donoghue, Activities Wise and Otherwise, p. 53.

65. Henry Augustus Robinson, Memories: wise and otherwise (London, Cassell and Co., 1923), pp. $185 ; 193$. 
66. W. F. Bailey to Augustine Birrell, 6 May 1914 enclosing [W. F. Bailey], "Parliamentary Divisions of the Province of Ulster, with the number of electors; the total population; the number of Roman Catholics; and the number of other denominations in each", 6 May 1914 (Oxford, Bodleian Library, Birrell papers, MS. Eng. c. 7035, ff. 72-7).

67. W. F. Bailey, "Exclusion of Ulster. Suggested delimitation of Area that might be excluded", 6 May 1914 (Ibid., f. 74-5).

68. W. F. Bailey to Augustine Birrell, 6 May 1914 and W. F. Bailey, "Exclusion of Ulster. Suggested delimitation of Area that might be excluded", 6 May 1914 (Ibid., ff. 72-7).

69. Ibid., f. 74 .

70. Ibid.

71. [Bailey], "Parliamentary Divisions of the Province of Ulster”, 6 May 1914 (Ibid., ff. 76-7).

72. Memorandum accompanying Dougherty to Birrell, 11 May 1914 (Oxford, Bodleian Library, Birrell papers, MS. Eng. c. 7034, f. 84).

73. "Valuations on $1^{\text {st }}$ March 1914" (Ibid., f. 59).

74. Robinson to Birrell, 6 May 1914 (Ibid., f. 67).

75. Ibid.

76. Ibid., f. 68r. Also cited in O Donoghue, Activities Wise and Otherwise, p. 181.

77. Robinson to Birrell, 6 May 1914 (Oxford, Bodleian Library, Birrell papers, MS. Eng. c. 7034, ff. 68v-69r); O Donoghue, Activities Wise and Otherwise, pp. 181-2.

78. Robinson to Birrell, 6 May 1914 (Oxford, Bodleian Library, Birrell papers, MS. Eng. c. 7034, f. 69r).

79. Bailey to Birrell, 6 May 1914 (Ibid., ff. 72v-73r).

80. Robinson to Birrell, 6 May 1914 (Ibid., f. 70r). Emphasis is in the original. On "The Ulsterman's minimum...", see O Donoghue, Activities Wise and Otherwise, p. 182.

81. Dougherty to Birrell, 7 May 1914 (Oxford, Bodleian Library, Birrell papers, MS. Eng. c. 7034, ff. 78-80).

82. Dougherty to Birrell, 11 May 1914 [plus enclosures] (Ibid., ff. 81-90).

83. Options for Ulster [Dougherty memorandum, 11 May 1914] (Ibid., ff. 88-9).

84. Robinson to Birrell, 6 May 1914 (Ibid., f. 70r).

85. Options for Ulster [Dougherty memorandum, 11 May 1914] (Ibid., ff. 87-8).

86. Ibid., ff. 89-90.

87. O Donoghue, Activities Wise and Otherwise, p. 183. See also, Gwynn, History of Partition, p. 116 et seq.

88. Hepburn, Catholic Belfast, p. 166. Other than Hepburn's reference, there is no comment on why Devlin was excluded. The reason seems to rest simply with the fact that all parties at the conference were allowed two delegates and Redmond and Dillon were the most senior and obvious choices. It may be inferred - but it is not stated anywhere - that Devlin was viewed as divisive and tarred with a sectarian brush through his involvement in the $\mathrm{AOH}$.

89. Laffan, Partition of Ireland, p. 44 and Gwynn, History of Partition, p. 116 et seq.

90. Laffan, Partition of Ireland, pp. 44-5.

91. For a full analysis of the conference see Conor Mulvagh, "Amicable in tone yet fruitless in result: politicians, press and public and the Buckingham Palace Conference, 1914", History Studies: University of Limerick History Society Journal, 8 (2007), pp. 77-92.

92. Thomas Hennessey, Dividing Ireland: World War I and Partition (London, Routledge, 1998), pp. 71-8.

93. Suspensory Act, 1914, and Government of Ireland Act, 1914 ( 4 \& 5 Geo. 5 c. 88 and c. 90).

94. Hennessey, Dividing Ireland, p. 145.

95. Devlin, memorandum of interview with Lord Northcliffe, marked 'secret', 15 May 1916 (National Library of Ireland, MS 15,181/3).

96. Ibid. 
97. O'Connor to Dillon, 18 May 1916 (Trinity College Dublin, MS 6741/308).

98. O'Connor to Dillon, 18 May 1916 (Ibid.).

99. R. F. Foster, Modern Ireland 1600-1972 (London, Penguin, 1989), p. 486.

100. Hepburn, Catholic Belfast, p. 176.

101. Eamon Phoenix, Northern Nationalism: Nationalist Politics, Partition and the Catholic Minority in Northern Ireland, 1890-1940 (Belfast, Ulster Historical Foundation, 1994), p. 22. Lloyd George's assurances to Carson (29 May 1916) are reproduced in Gwynn, History of partition, p. 149.

102. For a good synopsis of the dénouement of the 1916 Lloyd George scheme, see M. C. Rast, “The Ulster Unionists 'On Velvet' Home Rule and Partition in the Lloyd George Proposals, 1916”, American Journal of Irish Studies, 14 (2017), pp. 125-31.

103. A full breakdown of the voting in the Ulster Convention is contained in Hepburn, Catholic Belfast, p. 179.

104. R. B. McDowell, The Irish Convention, 1917-18 (London, Routledge and Kegan Paul, 1970), pp. 53-4.

105. Hennessey, Dividing Ireland, pp. 146-8.

\section{ABSTRACTS}

In April 1912, Prime Minister Herbert Henry Asquith introduced the third Home Rule (Government of Ireland) Bill to Westminster. In so doing, he ignited a crisis in both Ireland and Britain which consumed political discourse right up to the eve of the First World War and beyond. By September of 1912, the Ulster question took centre stage as the dominant issue holding back the constitutionally predetermined progress of the Government of Ireland Bill.

This article considers two important developments pertaining to Ulster within the broader Home Rule crisis. The first is the definition and rationalisation of a two-state solution to the so-called 'Irish question' which in 1914 resulted for the first time in the drafting of proposals for an Irish border, initially as a strictly temporary measure. The second theme here is to examine how, from November 1913 onwards, Nationalist politicians gradually and grudgingly came to accept, on a strictly temporary basis, the exclusion of a portion of the province of Ulster from the jurisdiction of a Home Rule parliament.

This culminated in the summer of 1916 with a convention of nationalist delegates from the six Ulster counties earmarked for exclusion. At this conference, the leading Nationalist MP in Ulster, Joseph Devlin, prevailed upon his followers to vote themselves temporarily out of a Home Rule Ireland so as to ensure the immediate enactment of Home Rule for the rest of the island. Although the deal upon which this pact was predicated failed, it marked the moment where Ulster nationalists consented to the principle of partition. The partition of Ireland became a reality in 1921 and has remained the bedrock of the two-state solution to the Irish question ever since.

En avril 1912, le Premier ministre Herbert Asquith introduisit le troisième projet de loi sur l'autonomie de l'Irlande (Government of Ireland Bill) au Parlement de Westminster. Ceci déclencha une crise qui influença le discours politique aussi bien en Irlande qu'en Grande-Bretagne et ce, jusqu'à la veille de la Première Guerre Mondiale et après. En septembre 1912, la question d'Ulster se trouva au centre des débats et devint l'obstacle prinicipal au progrès du projet de loi tel que défini par la constitution. 
Cet article examine deux éléments importants relatifs à l'Ulster dans le contexte plus large de la crise liée à la question du Home Rule. En premier lieu il s'agit de comprendre comment fut définie et rationalisée une solution à deux Etats à la question irlandaise, ce qui aboutit en 1914 à une ébauche des propositions de frontière irlandaise - solution qui, au départ, devait être strictement temporaire. Dans un second temps, il s'agira d'examiner comment, à partir de novembre 1913, les nationalistes en vinrent à accepter progressivement, à contre-coeur et sur une base strictement temporaire que soit exclue de la jurisdiction d'un parlement irlandais autonome une portion de la province d'Ulster.

La crise culmina à l'été 1916 lors d'une convention réunissant des délégués nationalistes de six comtés d'Ulster et destinée à décider l'exclusion. Dans ce contexte, le chef de file des députés nationalistes d'Ulster Joseph Devlin, convainquit ses soutiens de voter l'exclusion temporaire de leurs comtés afin que la mise en place immédiate de l'autonomie législative pour le reste de l'Irlande puisse être assurée. Bien que l'arrangement sur lequel reposait ce pacte se fût soldé par un échec, ceci marqua le moment où les nationalistes d'Ulster acceptèrent le principe de la partition. Cette partition d'Irlande devint une réalité en 1921 et demeure le fondement de la solution en deux Etats à la question irlandaise.

\section{INDEX}

Keywords: Home Rule, partition, nationalism, unionism, Ulster, Lloyd George

Mots-clés: Home Rule, partition, nationalisme, unionisme, Ulster, Lloyd George

\section{AUTHOR}

\section{CONOR MULVAGH}

Conor Mulvagh is Lecturer in Modern Irish History at the School of History, University College Dublin with special responsibility for the Decade of Centenaries (2013-23). His research centres primarily on British and Irish political history and the history of Ireland during the decade of the Irish revolution and the First World War. He is currently researching the history of UCD during the Irish Revolution. He is director of the UCD MA in Public History and lectures on memory and commemoration; the Irish revolution; and Northern Ireland. Recent publications include Irish Days, Indian Memories: V. V. Giri and Indian Law Students at University College Dublin, 1913-1916 (Irish Academic Press, 2016) and The Irish Parliamentary Party at Westminster, 1900-18 (Manchester University Press, 2016). He is a contributor to the landmark Cambridge History of Ireland (Cambridge University Press, 2018).

Conor Mulvagh enseigne l'histoire modern irlandaise à la faculté d'histoire de University College Dublin, où il est très impliqué dans les manifestations se déroulant dans le cadre de la Décennie des Centenaires (2013-2023). Ses recherches portent principalement sur l'histoire politique britannique et irlandaise pendant la décennie de la Révolution irlandaise et de la première guerre mondiale. Ses travaux actuels portent sur l'histoire de UCD sous la révolution irlandaise. Il est directeur du MA en histoire publique de UCD, et intervient sur les thèmes de la mémoire et de la commémoration, de la révolution irlandaise, et de l'Irlande du Nord. Parmi ses dernières publications, on mentionnera Irish Days, Indian Memories: V. V. Giri and Indian Law Students at University College Dublin, 1913-1916 (Irish Academic Press, 2016) et The Irish Parliamentary Party at Westminster, 1900-18 (Manchester University Press, 2016). Il a également participé à la Cambridge History of Ireland (Cambridge University Press, 2018). 